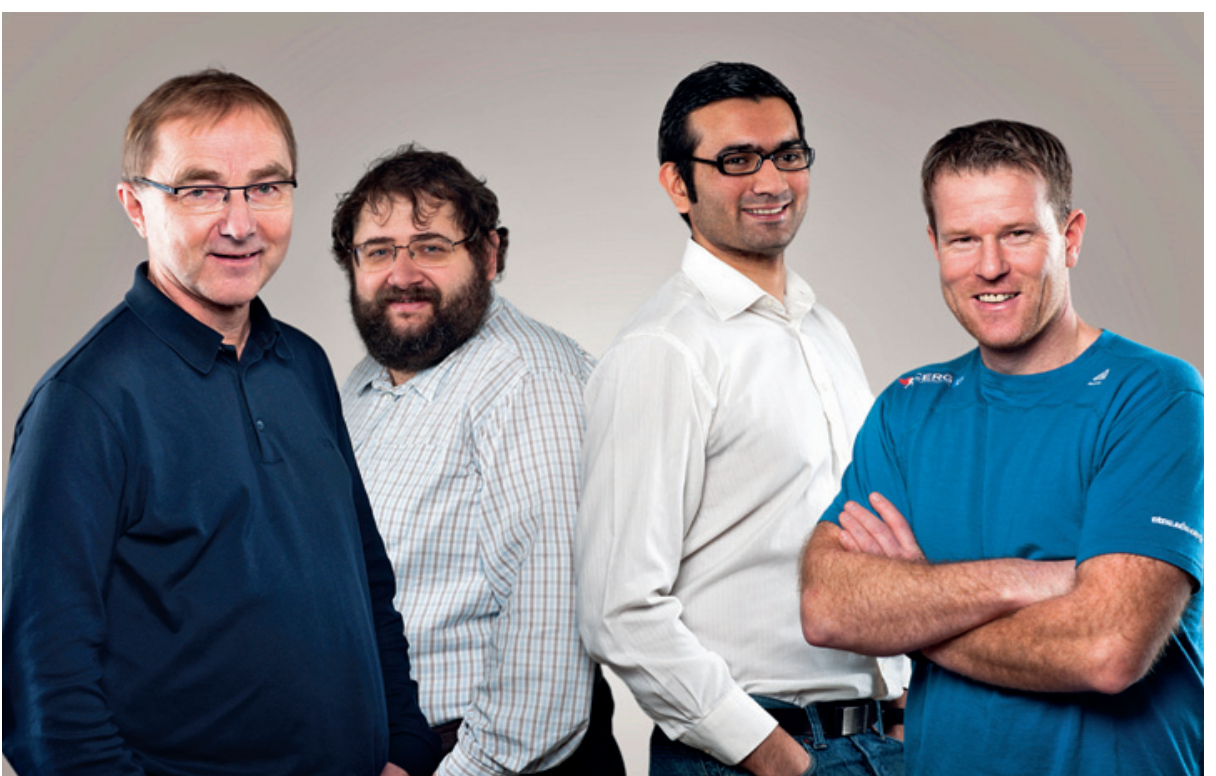

De fire artikkelforfatterne. Fra venstre Lars J. Vatten, Imre Janszky, Javaid Nauman og Ulrik Wisløff. Foto Lars Berre

\title{
Økt hvilepuls - økt risiko for hjertedød
}

Høy hvilepuls er assosiert med økt sykelighet og dødelighet, både blant friske menn og kvinner og i ulike pasientgrupper. Det viser ny norsk forskning.

Hvilepulsen endrer seg over tid, mest på grunn av alder, fysisk aktivitet og medisinering. Det er få studier om sammenhengen mellom endring i hvilepuls over tid og risiko for fremtidig død. I de studiene hvor man har undersøkt dette, ser man at økt hvilepuls er assosiert med økt risiko for prematur død både blant friske og blant personer med kardiovaskulær sykdom. Ingen har til nå undersøkt sammenhengen mellom endringer $\mathrm{i}$ hvilepuls og risiko for iskemisk hjertedød.

Data fra de to første rundene av Helseundersøkelsene i Nord-Trøndelag (HUNT 1 og 2) ble koblet med data fra Dødsårsaksregisteret. Studien omfattet 13499 friske menn og 15826 friske kvinner. Personer som hadde en hvilepuls $<70 \mathrm{slag} / \mathrm{min}$ i HUNT 1, men > $85 \mathrm{slag} / \mathrm{min}$ i HUNT 2, hadde dobbelt så høy risiko for å dø av iskemisk hjertesykdom i løpet av de neste 12 årene, sammenliknet med personer som hadde hvilepuls $<70 \mathrm{slag} / \mathrm{min}$ ved begge målingene. Blant personer med hvilepuls på 70-85 slag/min i HUNT 1, men lavere hvilepuls i HUNT 2, var dødeligheten omtrent halvert, sammenliknet med personer som hadde hvilepuls på $70-85 \mathrm{slag} / \mathrm{min}$ ved begge målingene.

- Resultatene kan tyde på at måling av hvilepulsen over tid kan være en enkel og nyttig metode for å identifisere tilsynelatende friske personer som kan ha en underliggende iskemisk hjertesykdom, sier professor Ulrik Wisløff ved Institutt for sirku- lasjon og bildediagnostikk ved Norges teknisk-naturvitenskapelige universitet, som ledet studien.

\section{Senter for hjertetrening}

Artikkelen er skrevet av postdoktorene Javaid Nauman og Imre Janszky samt professorene Lars J. Vatten og Ulrik

Wisløff. Studien er initiert av forskere ved K.G. Jebsen - Senter for hjertetrening (www.ntnu.no/cerg), som består av leger og forskere ved Norges teknisk-naturvitenskapelige universitet og St. Olavs hospital.

Forskerne bruker data fra store befolkningsstudier, studier av pasienter og eksperimentelle studier på molekyl- og cellenivå. De forventer å identifisere nye biomarkører for både negative (som følge av inaktivitet) og positive (som følge av fysisk aktivitet) molekylære mekanismer som vil danne grunnlag for et nytt diagnostisk og terapeutisk verktøy for å bedre behandlingen av hjertesykdom, og for å hindre utviklingen av hjerte- og karsykdom.

\section{Erlend Hem}

erlend.hem@medisin.uio.no

Tidsskriftet

\section{Litteratur}

1. Nauman J, Janszky I, Vatten LJ et al. Temporal changes in resting heart rate and deaths from ischemic heart disease. JAMA 2011; 306: 2579-87.

Artikkelen ble publisert først på nett 21.12. 2011.
Ordforklaringer

HUNT: Helseundersøkelsene i Nord-Trøndelag er Norges største samling av helseopplysninger om en befolkning. Data er fremskaffet gjennom tre befolkningsundersøkelser, HUNT 1 (1984-86), HUNT 2 (1995-97) og HUNT 3 (2006-08). Flere enn 100000 personer har samtykket til at anonymiserte helseopplysninger kan gjøres tilgjengelig for godkjente forskningsprosjekter.

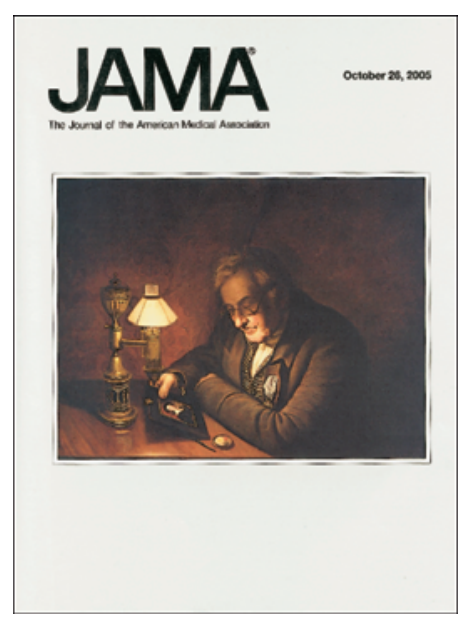

Artikkelen ble publisert 21.12.2011 i JAMA (www.jama.com), som regnes som en av de «fem store» innen medisinsk publisering ved siden av New England Journal of Medicine, BMJ, Annals of Internal Medicine og The Lancet 